\title{
Impact of Early Marriage on Childhood Stunting
}

\author{
$1^{\text {st }}$ Heru Subaris Kasjono \\ Poltekes Kemenkes RI Yogyakarta \\ Yogyakarta, Indonesia \\ heru.subarisk@poltekkesjogya.ac.id
}

\author{
$4^{\text {th }}$ Dina Fadillah \\ Poltekes Kemenkes RI Yogyakarta \\ Yogyakarta, Indonesia
}

\author{
$2^{\text {nd }}$ Agus Wijanarko \\ Poltekes Kemenkes RI Yogyakarta \\ Yogyakarta, Indonesia
}

$5^{\text {th }}$ Wahyu Wijanarko

Poltekes Kemenkes RI Yogyakarta

Yogyakarta, Indonesia

\author{
$3^{\text {rd }}$ Rizki Amelia \\ Poltekes Kemenkes RI Yogyakarta \\ Yogyakarta, Indonesia
}

\author{
$6^{\text {th }}$ Sutaryono \\ Department of Pharmacy \\ Sekolah Tinggi Ilmu Kesehatan Muhammadiyah \\ Klaten, Indonesia
}

\begin{abstract}
Pregnancy requires increased iron needs, while teenage pregnancy also needs iron for growth. As a result, teenage pregnancy has an impact on the risk of stunting in their children. The purpose of this study is to prove the relationship between early marriage and the risk of stunting in children. The design of this study was observational using a cross-sectional method with a quantitative approach. The study was conducted at 8 Community Health Centers in West Bangka Regency, Bangka Belitung Islands Province, Indonesia, during October-November 2018. The research sample consisted of 310 children aged 0-59 months. To find out the age at marriage, the researcher used interviews as primary data and records from Puskesmas, Office of Religious Affairs, the measurement of antopometry of stunting data or nutritional status of children under-five as secondary data. The analysis of the results used Odds Ratio and Chi-Square test of $95 \%$ confidence interval. The results from 8 health centers showed that the highest incidence of early marriage (under 20 years old) by engaging teenage pregnant who had stunting children were at the Kundi Health Center (78.6\%) and Sekar Biru Health Center $(83,3 \%)$. There was a significant relationship between the early married teenage and stunting in their children $(O R=$ $1,724 ; 95 \% C I=1,088-2,732 ; p=0.020)$. Early marriage (under20 years old) increases the risk of stunting in children. Therefore, it is necessary to educate and regulate the marriageable age.
\end{abstract}

\section{Keywords-Early Marriage, Childhood, Stunting}

\section{INTRODUCTION}

The prevalence of stunting nationwide Indonesia in the last five years is said to be high, research in 2013 showed $30.7 \%$ and in 2018 increased to $30.8 \%$. According to the World Health Organization said the prevalence of stunting higher when reaching $30 \%-39 \%$ and is said to be very high if the prevalence was $\geq 40 \%$, related to the proportion of undernourished and poor in infants showed $17.7 \%$ figure, very short and short $19.3 \%$, very thinner and thinner $10.2 \%$ And fat $8 \%$ [1][2][3].

Stunting defined as height for age under -2 standard curve median growth of children. Stunting is a chronic condition on the poor linear growth of a child, which is accumulating the impact of various factors, such as poor nutrition and health after the birth of the child [1][4].

Some studies show that children in the toddler period who suffered stunting have low cognitive levels, bad academic achievement, and psychosocial. Children who experience severe stunting in the first two years of life have a very strong relationship to cognitive delays in later childhood and long-term impact on the quality of the resource. The incidence of stunting since childhood has been associated with delayed motor development and a lower level of intelligence. Other studies have shown that stunting children (9-24 months) have either a lower level of intelligence ora lower valuation on locomotor, coordination of hand and eye, hearing, speaking, and performance if they are compared to normal children[4].

The government effort issued a policy of regulation 42/2013, which establishes a national movement Thousand Day One Life to improve the nutritional status of children, followed by a development program including its budget. Stunting has a length of the PTM risk in adulthood, although it can be corrected at an early age. Stunting is a chronic nutritional problem caused by multifactorial and is intergenerational.

Based on the results of Riskesdes 2018, it was known that Bangka Belitung Province was one province that experienced problems, such as nutritional status in the category of short and short for the children age in percentage of $23.6 \%$ and $17 \%$ of malnutrition. Through the Secretariat of the Vice President in the book "100 District/City of Child Intervention Priority for Stuntingestablished Bangka Regency West as one of 100 Regencies/Cities. West Bangka regency was also the only district in Bangka Belitung Islands that was included in the 100 districts with 10 villages priority[3][5].

West Bangka Regency was one of the cities that experienced stunting problems based on the result of Riskesdes 2013. Prevalence overview of evidence-based children under-five nutrition status derived from the Basic Health Research results become one of the bases to establish evidence-based policies, including the prevalence of malnutrition(underweight) on baduta child (under two years old), conducted once for 3-5 years. For the availability information on the progress of nutritional status and gains of nutrition in a region of rapidly, accurately, organizingly and sustainability among Riskesdas implementation are necessary to monitor and evaluate each year[6].

Based on Stunting data in West Bangka on the initial survey conducted in January 2018, it was known that there was a village with the highest number of cases of stunting, namely Peradong village which had $47.06 \%$ higher than the 10 villages of stunting intervention priorities 
established by the government. Data of 10 villages in West Bangka stunting were Tugang village that measured 123 of 290 children under-five or $42.41 \%$ had stunting, Tuik village had 15 stunting children of 59 children underfive found or equal to $25.42 \%$, Rukam village measured 27 of 115 children under-five suffered stunting are 27 or $23.48 \%$, Petar Tumbak village had 67 of 291 children under-five suffering stunting or equal to $23.02 \%$, Simpang Tiga village had 74 of 178 children under five suffering stunting or around $41.57 \%$.

Reproductive health is one predisposing factor found to prevent stunting. Maintaining adolescent reproductive health and avoiding early marriage is an example. Those are positive efforts in the development growth of reproductive organs perfectly. The good immune power of a child also influences the occurrence of stunting. Therefore, we hypothesized that one of the causes of the high rate of stunting in Bangka Belitung is early marriage.

\section{METHOD}

This study used a cross-sectional study with a quantitative approach. The experiment was conducted at 8 health centers in West Bangka Bangka Belitung Islands Indonesia in October-November 2018. The research sample consisted of 310 children aged 0-59 months. To find out the age at marriage, the researcher used interviews as primary data and records from Puskesmas, Office of Religious Affairs, the measurement of antopometry of stunting data or nutritional status of children under-five as secondary data. The analysis of the results used Odds Ratio and the Chi-Square test of $95 \%$ confidence interval.

\section{RESULTS AND DISCUSSION}

Research conducted in West Bangka Bangka Belitung Islands Indonesia found that the number of children under five suffering stunting was 2,175 children under-five. Based on the sample, children aged 0-59 months were 310 children Besides, it found that married women were at an average of 20:18. The youngest age was 15 years old and the oldest was 35 years old. In this study, the researcher categorized marriage age into $\leq 20$ years and over 20 years. Distribution of the incidence of stunting by the age of marriage maternal in the health centers shown in Table 1:

TABLE 1. DISTRIBUTION OF THE INCIDENCE OF STUNTING BY THE AGE OF THE MOTHER'S MARRIAGE IN THE AREA OF HEALTH CENTERS (PUSKESMAS)

\begin{tabular}{|l|l|c|c|c|c|c|}
\hline \multirow{2}{*}{ PHC } & \multirow{2}{*}{$\begin{array}{c}\text { Age at } \\
\text { Marriage }\end{array}$} & \multicolumn{2}{|c|}{ Stunting } & \multicolumn{2}{c|}{$\begin{array}{c}\text { Not } \\
\text { Stunting }\end{array}$} & Total \\
\cline { 3 - 7 } & & $\mathrm{n}$ & $\%$ & $\mathrm{n}$ & $\%$ & \\
\hline \multicolumn{2}{|l|}{ Spn Teritip } & & & & & \\
\hline & $\leq 20$ & 20 & 66.7 & 18 & 60 & 38 \\
\hline & $>20$ & 10 & 33.3 & 12 & 40 & 22 \\
\hline Jebus & & & & & & \\
\hline & $\leq 20$ & 15 & 62.5 & 11 & 45.8 & 26 \\
\hline & $>20$ & 9 & 37.5 & 13 & 54.2 & 22 \\
\hline Kelapa & & & & & & \\
\hline
\end{tabular}

\begin{tabular}{|c|c|c|c|c|c|c|}
\hline & $\leq 20$ & 29 & 65.9 & 24 & 54.5 & 53 \\
\hline & $>20$ & 15 & 34.1 & 20 & 45.5 & 35 \\
\hline \multicolumn{7}{|l|}{ Sekar biru } \\
\hline & $\leq 20$ & 5 & 83.3 & 2 & 33.3 & 7 \\
\hline & $>20$ & 1 & 16.7 & 4 & 66.7 & 5 \\
\hline \multicolumn{7}{|l|}{ Puput } \\
\hline & $\leq 20$ & 3 & 60.0 & 4 & 80 & 7 \\
\hline & $>20$ & 2 & 40.0 & 1 & 20 & 3 \\
\hline \multicolumn{7}{|l|}{ Munthok } \\
\hline & $\leq 20$ & 10 & 62.5 & 6 & 37.5 & 16 \\
\hline & $>20$ & 6 & 37.5 & 10 & 62.5 & 16 \\
\hline \multicolumn{7}{|l|}{ Kundi } \\
\hline & $\leq 20$ & 11 & 78.6 & 9 & 64.3 & 20 \\
\hline & $>20$ & 3 & 21.4 & 5 & 35.7 & 8 \\
\hline \multicolumn{7}{|l|}{ Tempilang } \\
\hline & $\leq 20$ & 11 & 68.8 & 10 & 62.5 & 21 \\
\hline & $>20$ & 5 & 31.2 & 6 & 37.5 & 11 \\
\hline \multicolumn{6}{|c|}{ Total } & 310 \\
\hline
\end{tabular}

The proportion of incidence of stunting by the age of marriage at the health center in Kundi and Sekar biru was the most (over 70\%). The relationship between a mother's age of marriage with the incidence of stunting based on bivariate analysis showed data as the following table 2 .

TABLE 2. THE RELATIONSHIP BETWEEN A MOTHER'S AGE OF MARRIAGE AND THE INCIDENCE OF STUNTING

\begin{tabular}{|c|c|c|c|c|c|}
\hline \multirow[t]{2}{*}{ Stunting } & \multicolumn{2}{|l|}{ Age } & \multirow{2}{*}{$\begin{array}{c}\mathrm{p} . \\
\text { value }\end{array}$} & \multirow[t]{2}{*}{ OR } & \multirow[t]{2}{*}{ CI 95\% } \\
\hline & $\leq 20$ yo & $>20$ & & & \\
\hline Yes & 104 & 51 & \multirow{3}{*}{0020} & \multirow{3}{*}{1,724} & \multirow{3}{*}{$1088-2732$} \\
\hline Not & 84 & 71 & & & \\
\hline Total & 188 & 122 & & & \\
\hline
\end{tabular}

OR, Odds Ratio; CI, Confidence Interval

The relationship test using the Chi-Square test with result $\mathrm{p}=0,020$ means that there is a significant relationship between the age of married mothers and the incidence of stunting. On the other hand, risk factors of odds ratio value obtained were 1724 (CI: 1.088 to 2.732 ) It meant that the risk of married women less than 20 years and the incidence of stunting occurred 1.7 times rather than women who were married more than 20 years.

Based on the variables that have the risk factors with the incidence of stunting in the district of West Bangka, early marriage age (under 20 years) is still a lot. Early growth and development of biological adolescents begin with puberty. The persistence of the traditional practice of early marriage in the countries in Southeast Asia also contributes to iron deficiency anemia. Early marriage among adolescents is generally associated with early pregnancy, and pregnancy increases the need for iron and affects the lack of iron deficiency and iron-deficiency anemia experienced by adolescent girls[7].

About $1,000 \mathrm{mg}$ of iron is needed to support the changes associated with pregnancy, such as increased 
blood volume, growth and development of the fetus were ideal It takes about $300 \mathrm{mg}$ of iron. Most pregnant women, both in developing countries and developed countries, it has a little iron store in early pregnancy. Teenage pregnancy becomes riskier because of increased iron requirements during pregnancy added by the need for iron during growth spurt [8]. The effect of nutritional status on the reproductive system means energy and nutrition needs are influenced by reproductive age, activity level, and nutritional status. Nutrients are needed to fulfill the growing needs. A nutritional deficiency with anemia and underweight mainly bear LBW babies if it is compared to women of reproductive age who are safe for pregnant[9].

There are other factors causing stunting, namely direct and indirect factor. Direct factors were determined by the intake of food, birth weight, and disease, while the indirect factors were such as economic, cultural, education and employment, health-care facilities. Socioeconomic factors interact with one another as the input of nutrients, birthweight and infectious diseases in children who are stunted due to lack of food intake and disease recurring primarily infectious diseases that can increase metabolic demands and reduce appetite, thus the impact occurs abnormalities in short form despite factor genes in cells show potential to grow normally. Results of other studies also show that children exposed to secondhand smoke increase the incidence of asthma exacerbations consequently decreased appetite[10][11].

One of the main factors causing stunting toddler is eating. An Unbalanced eating pattern will affect nutrient intake, especially the intake of nutrients that play a role in the growth of children. Eating pattern affects the incidence of stunting [12]. Stunting in children under-five is more common in children who had a simple menu arrangement which only consists of rice, side dishes, and vegetables. An unbalanced eating pattern causes disproportionate unmet nutritional needs of children, especially the intake of micro-nutrients[13].

It is, therefore, necessary in-depth study on eating patterns and other factors that have not been conducted in this study, thus it can be a major cause of the incident multivariate stunting in children under-five in West Bangka Bangka Belitung Islands, Indonesia.

\section{CONCLUSION}

Mother with early marriage increases the risk of stunting in children. The effort required is to educate teens and tighten the regulations regarding the age of marriage.

\section{REFERENCES}

[1] World Health Organization (2010), Nutrition Landscape Information System (NLIS) country profile indicators: interpretation guide. ISBN 9789241599955 Geneva: WHO.

[2] Litbang Kemenkes RI, 2013, Riset Kesehatan Dasar Tahun 2013 , Badan Penelitian dan Pengembangan Kesehatan Kemenkes RI, Jakarta

[3] Litbang Kemenkes RI, 2018, Hasil Utama Riset Kesehatan Dasar Tahun 2018, Badan Penelitian dan Pengembangan Kesehatan Kemenkes RI, Jakarta

[4] Anita. (2011). Dukungan Keluarga dan Kejadian Stunted pada Anak Balita di Kabupaten Simeulue. Tesis. Minat Kesehatan Ibu dan Anak-Kesehatan Reproduksi. Program Studi Ilmu Kesehatan Masyarakat, Fakultas Kedokteran Universitas Gadjah Mada. YogyakartaPerpres No.42/2013

[5] [TNP2K] Tim Nasional Percepatan Penanggulangan Kemiskinan. 2011. Panduan Penanggulangan Kemiskinan: Buku Pegangan Resmi TKPK Daearah. Sekretariat Wakil Presiden Republik Indonesia. Jakarta.

[6] PERSAGI. Stop Stunting dengan Konseling Gizi. Jakarta: Penebar Swadaya Grup; 2018.

[7] World Health Organization (WHO). 2011. Nutrition: Complementary feeding.

[8] Pan American Health Organization-World Health Organization (PAHO-WHO). 2010. Guiding Principles for Complementary Feeding of The Breast Feeding Child. Washington, DC: Pan American Health Organization.)

[9] Marmi. 2013. Gizi Dalam Kesehatan Reproduksi. Yogyakarta : Pustaka Pelajar.

[10] Chesters J.K, Zinc. Di dalam B.L. O'dell and R.A. Sunde (Eds). Handbook of Nutritionally Essential Mineral Elements. Marcel Dekker, Inc. New York. pp. 185-214.)

[11] Sutaryono, N. A. P. Hartono, P. Setyono, S. Budiastuti, and M. M, "Paparan Asap Rumah Tangga Dan Lama Waktu Serangan Asma Pada Anak," in Prosiding - Semnas \& Call For Papers, 2017, pp. 49-53.

[12] Aramico, B., T. Sudargo., dan J. Susilo. 2013. Hubungan Sosial Ekonomi, Pola Asuh, Pola Makan dengan Stunting pada Siswa Sekolah Dasar di Kecamatan Lut Tawar, Kabupaten Aceh Tengah. Jurnal Gizi dan Dietik Indonesia, 1(3): 121-130.

[13] (Bayu Dwi Welasasih, 2012, Some Factors Associated with Nutritional Status Stunting, Departemen Gizi Kesehatan Fakultas Kesehatan Masyarakat Universitas Airlangga, Vol. 8 - No. 3 / 2012-03 